\title{
Lactobacterium zeae Kuznetsov, a Later Subjective Synonym of Lactobacillus casei (Orla-Jensen) Hansen and Lessel
}

\author{
CHARLES K. MILLS and ERWIN F. LESSEL
}

American Type Culture Collection, Rockville, Maryland 20852

\begin{abstract}
Lactobacterium zeae Kuznetsov strain USSR RIA 482, here designated as the type strain of Lactobacterium zeae, was accessioned by the American Type Culture Collection (as ATCC 15820), where, on the basis of its phenetic characters, it was identified as belonging to Lactobacillus casei. To confirm this identification, the deoxyribonucleic acid (DNA) base compositions of and the nucleic-acid homology between this strain and ATCC 393, the neotype strain of Lactobacillus casei, were determined. ATCC 15820 showed a high DNA homology value (82\%) with ATCC 393 as well as good agreement in DNA base composition ( 48.0 and $49.0 \mathrm{~mol} \%$ guanine plus cytosine, respectively). On the basis of the overall evidence, ATCC 15820 is here regarded as belonging to Lactobacillus casei, and Lactobacterium zeae Kuznetsov 1959 is therefore a later subjective synonym of Lactobacillus casei (Orla-Jensen 1919) Hansen and Lessel 1971.
\end{abstract}

In 1959, Kuznetsov (7) isolated from cornsteep liquor a lactic acid bacterium which he designated as a new species, Lactobacterium zeae. Five years later, Kuznetsov deposited strain USSR RIA 482 in the American Type Culture Collection (ATCC), where it was accessioned under the number 15820. This strain was stated by Kuznetsov in a personal communication to the ATCC to be the type strain; however, to our knowledge the type strain of this species has not been formally designated in the literature. During the processing of this strain at the ATCC, similarities were noted between it and Lactobacillus casei. Consequently a study was undertaken to determine what relationship, if any, exists between Lactobacterium zeae and Lactobacillus casei. The purposes of this paper are to report the results of this study and to designate the type strain of Lactobacterium zeae.

\section{MATERIALS AND METHODS}

Bacterial strains. The strains employed in this study were Lactobacterium zeae ATCC 15820 , received by the ATCC from V. D. Kuznetsov as USSR RIA 482, and Lactobacillus casei ATCC 393, the neotype strain of Lactobacillus casei (4). Both strains are documented in the ATCC Catalogue of Strains (8).
Media and methods. The media and methods used for the phenetic characterization of the strains studied were described previously $(9,10,12)$. Additional tests, cited below, were performed on Lactobacterium zeae ATCC 15820 to insure that it has retained the characters of the species as originally given by Kuznetsov (7) and that it is thereby suitable for designation as the type strain.

Hydrogen sulfide production was determined using Kligler iron agar (2). The indole test was performed as described by Edwards and Ewing (3).

For the determination of the production of volatile acids and alcohols by ATCC 15820 , cultures were grown in de Man-Rogosa-Sharpe (MRS) broth (1) without acetate and then analyzed by gas chromatography. Preparation of the samples was as previously described (5). A Perkin Elmer gas chromatography apparatus (model 881) equipped with a hydrogenflame ionization detector and a Speedomax recorder (Leeds and Northrup) was used. The gas chromatography apparatus was fitted with stainless-steel columns (6 feet by $1 / 8$ inch) with a liquid phase of $3 \%$ ECNSS-M on $80 / 100$ mesh chromosorb G. Helium at a flow rate of $120 \mathrm{ml} / \mathrm{min}$ was the carrier gas. The column temperature was held at $100 \mathrm{C}$ for $5 \mathrm{~min}$ after sample injection. It was then programmed to $200 \mathrm{C}$ with a rate of $4 \mathrm{C} / \mathrm{min}$. The injector and detector heaters were at $120 \mathrm{C}$.

The antibiotic sensitivities of ATCC 15820 were determined as follows. A sterile cotton swab was dipped into a 24-h-old MRS broth culture and then rotated against the upper inside wall of the test tube containing the culture to express the excess fluid. The 
entire surface of an MRS agar plate was streaked with the cotton swab three times, the plate having been turned approximately 60 degrees between streakings. The plate was held at room temperature for about 5 min. Sensi-discs (BBL Division of BioQuest, Cockeysville, Md.) were aseptically applied to the agar surface with forceps. The discs were placed so that their centers were at least $30 \mathrm{~mm}$ apart from each other and were pressed down with the forceps to assure complete contact with the agar surface. Incubation was at $37 \mathrm{C}$ for $24 \mathrm{~h}$. A clear zone around a disc was interpreted as complete inhibition of growth by the antibiotic in the disc.

The data on the guanine plus cytosine $(G+C)$ contents of the deoxyribonucleic acids (DNA) were provided by $M$. Mandel; they were averages of duplicate $\mathrm{CsCl}$ buoyant density determinations (13).

The determination of nucleic acid relatedness was made by J. L. Johnson by a previously described method (6).

\section{RESULTS AND DISCUSSION}

The characters determined in common for the strains studied are recorded in Table 1. Additional characters determined for Lactobacterium zeae ATCC 15820 are as follows. Surface colonies on MRS agar were smooth, glistening, and white, and measured 1 to $2 \mathrm{~mm}$ in diameter; hydrogen sulfide was not produced; the test for indole was negative; a small amount of acetic acid was detected after growth in MRS broth; litmus milk was curdled in 2 to 4 days (the 10th edition of the ATCC Catalogue of Strains [8] incorrectly states that litmus milk is not curdled); the benzidine test was negative; growth occurred at $48 \mathrm{C}$; and growth was inhibited by penicillin $(10 \mathrm{U})$, terramycin $(30 \mu \mathrm{g})$, tetracycline $(30 \mu \mathrm{g})$, and ery thromycin $(15 \mu \mathrm{g})$, but not by streptomycin $(10 \mu \mathrm{g})$ or dihydrostreptomycin $(10 \mu \mathrm{g})$. The characters of ATCC 15820 are in complete agreement with those originally reported by Kuznetsov (7) for Lactobacterium zeae, and this strain is therefore designated here as the type strain of this species.

A comparison of the phenetic characters of the strains studied (Table 1) shows that Lactobacterium zeae ATCC 15820 and Lactobacillus casei ATCC 393 are identical except for the fermentation of rhamnose by the former; this character is negative for ATCC 393. Furthermore, ATCC 15820 shows a high level $(82 \%)$ of nucleic acid homology with ATCC 393 and has a $\mathrm{G}+\mathrm{C}$ content in its DNA similar to that of ATCC 393 (48.0 and $49.0 \mathrm{~mol} \%$, respectively). According to the overall evidence, ATCC 15820 is a strain of Lactobacillus casei which differs only slightly from the neotype strain of Lactobacillus casei.

From the data presented, it is clear that the type strain of Lactobacterium zeae resembles

TABLE 1. A comparison of the phenetic characters of Lactobacterium zeae ATCC 15820 with those of Lactobacillus casei ATCC 393

\begin{tabular}{|c|c|c|}
\hline Characters & ATCC 15820 & ATCC 393 \\
\hline Gram-positive rods & + & + \\
\hline Cell dimensions & 0.6 by $2.4 \mu \mathrm{m}$ & 0.5 by $1.2 \mu \mathrm{m}$ \\
\hline Endospores & - & - \\
\hline Motility & - & - \\
\hline Catalase & - & - \\
\hline Nitrate reduction & - & - \\
\hline $\begin{array}{l}\text { Gelatin lique- } \\
\text { faction }\end{array}$ & - & - \\
\hline $\begin{array}{c}\text { Ammonia from } \\
\text { arginine }\end{array}$ & - & - \\
\hline $\begin{array}{l}\text { Type of lactic } \\
\text { acid produced }\end{array}$ & $\mathrm{L}(+)$ & $\mathbf{L}(+)$ \\
\hline Gas from glucose & - & - \\
\hline Gas from gluconate & + & + \\
\hline Acid from: & & \\
\hline Amygdalin & + & + \\
\hline Arabinose & - & - \\
\hline Cellobiose & + & + \\
\hline Dextrin & - & - \\
\hline Fructose & + & + \\
\hline Galactose & + & + \\
\hline Gluconate & + & + \\
\hline Glucose & + & + \\
\hline Inositol & - & - \\
\hline Inulin & - & - \\
\hline Lactate & - & - \\
\hline Lactose & + & + \\
\hline Maltose & + & + \\
\hline Mannitol & + & + \\
\hline Mannose & + & + \\
\hline Melezitose & + & + \\
\hline Melibiose & - & - \\
\hline Raffinose & - & - \\
\hline Rhamnose & + & - \\
\hline Ribose & + & + \\
\hline Salicin & + & + \\
\hline Sorbitol & - & - \\
\hline Sorbose & - & - \\
\hline Starch & - - & - \\
\hline Sucrose & + & + \\
\hline Tagatose $^{a}$ & + & + \\
\hline Trehalose & + & + \\
\hline Turanose $^{a}$ & + & + \\
\hline Xylose & - & - \\
\hline $\begin{array}{l}\text { Hydrolysis of } \\
\text { esculin }\end{array}$ & + & + \\
\hline Growth at $15 \mathrm{C}$ & + & + \\
\hline Grow th at $45 \mathrm{C}$ & + & + \\
\hline Malic enzyme ${ }^{b}$ & + & + \\
\hline
\end{tabular}

${ }^{a}$ M. Rogosa, personal communication.

$b$ J. London, personal communication. 
very closely the neotype strain of Lactobacillus casei. The name of the former is therefore a later subjective synonym of the latter inasmuch as the names are based on different type (or neotype) strains which are regarded as belonging to one and the same species.

Our preliminary attempts to assign Lactobacterium zeae ATCC 15820 to one of the currently recognized subspecies of Lactobacillus casei resulted in the realization that subspeciation within Lactobacillus casei is a rather complex taxonomic problem. As one example, according to our observations the phenetic characters of ATCC 15820 indicate that this strain should be placed in Lactobacillus casei subsp. rhamnosus, but the DNA hybridization data indicate a much closer relationship of this strain to Lactobacillus casei subsp. casei than to Lactobacillus casei subsp. rhamnosus. However, this problem of subspeciation falls outside the scope of this paper, and it will be the subject of a future investigation.

\section{ACKNOWLEDGMENTS}

We are indebted to J. L. Johnson for performing the nucleic acid homology study, to $J$. London for the data on the malic enzymes, to M. Mandel for providing the data on the base compositions of the DNAs, and to M. Rogosa for the results of the fermentation of tagatose and turanose.

\section{REPRINT REQUESTS}

Address requests for reprints to: Mr. Charles K. Mills, American Type Culture Collection, 12301 Parklawn Drive, Rockville, Md. 20852.

\section{LITERATURE CITED}

1. de Man, J. C., M. Rogosa, and M. E. Sharpe. 1960.
A medium used for the cultivation of lactobacilli. J. Appl. Bacteriol. 23:130-135.

2. Difco Laboratories. 1953. Difco manual, 9 th ed. Detroit, Michigan.

3. Edwards, P. R., and W. H. Ewing. 1972. Identification of Enterobacteriaceae, 3rd ed. Burgess Publishing Co., Minneapolis.

4. Hansen, P. A., and E. F. Lessel. 1971. Lactobacillus casei (Orla-Jensen) comb. nov. Int. J. Syst. Bacteriol. 21:69-71.

5. Holdeman, L. V., and W. E. C. Moore (ed). 1972. Anaerobe Laboratory Manual. V. P. I. Anaerobe Laboratory, Virginia Polytechnic Institute and State Úniversity, Blacksburg, Va.

6. Johnson, J. L., and C. S. Cummins. 1972. Cell wall composition and deoxyribonucleic acid similarities among the anaerobic coryneforms, classical propionibacteria, and strains of Arachnia propionica. J. Bacteriol. 109: 1047-1066.

7. Kuznetsov, V. D. 1959. A new species of lactic acid bacteria. Mikrobiologiya 28:248-351.

8. Lessel, E. F., and H. Hatt (ed). 1972. Collection of bacteria. In The American Type Culture Collection Catalogue of Strains, 10th ed. The American Type Culture Collection, Rockville, Md.

9. London, J., E. Y. Meyer, and S. R. Kulczyk. 1971. Detection of relationships between Streptococcus faecalis and Lactobacillus casei by immunological studies with two forms of malic enzyme. J. Bacteriol. 108:196-201.

10. Mills, C. K., and E. F. Lessel. 1973. Designation and description of the type strain of Lactobacillus casei subsp. alactosus Rogosa et al. Int. J. Syst. Bacteriol. 23:67-68.

11. Orla-Jensen, S. 1919. The lactic acid bacteria. Andr. Fred. Hast and Son, Copenhagen.

12. Rogosa, M., R. F. Wiseman, J. A. Mitchell, M. N. Disraily, and A. J. Beamon. 1953. Species differentiation of oral lactobacilli from man including descriptions of Lactobacillus salivarius nov. sp. and Lactobacillus cellobiosus nov. sp. J. Bacteriol. 65:681-699.

13. Schildkraut, C. L., J. Marmur, and P. Doty. 1962. Determination of the base composition of deoxyribonucleic acid from its buoyant density in $\mathrm{CsCl}$. J. Mol. Biol. 4:430-443. 